\title{
Expression of the developmental I antigen by a cloned human cDNA encoding a member of a $\beta-1,6-N$-acetylglucosaminyltransferase gene family
}

\author{
Marti F.A. Bierhuizen, ${ }^{1}$ Marie-Geneviève Mattei, $^{2}$ and Minoru Fukuda ${ }^{1,3}$ \\ ${ }^{1}$ La Jolla Cancer Research Foundation, Cancer Research Center, La Jolla, California 92037 USA.; ${ }^{2}$ Groupe Hospitalier de la \\ Timone, U242 Institut National de la Santé et de la Recherche Médicale, 13385 Marseille, Cedex 5, France
}

\begin{abstract}
The blood group $i / I$ antigens were the first identified alloantigens that display a dramatic change during human development. The $i$ and $I$ antigens are determined by linear and branched poly- $N$-acetyllactosaminoglycans, respectively. In human erythrocytes during embryonic development, the fetal (i) antigen is replaced by the adult (I) antigen as a result of the appearance of a $\beta-1,6-N$-acetylglucosaminyltransferase, the I-branching enzyme. Here,we report the cDNA cloning and expression of this branching enzyme that converts linear into branched poly- $N$-acetyllactosaminoglycans, thus introducing the I antigen in transfected cells. The cDNA sequence predicts a protein with type II membrane topology as has been found for all other mammalian glycosyltransferases cloned to date. The Chinese hamster ovary cells that stably express the isolated cDNA acquire I-branched structures as evidenced by the structural analysis of glycopeptides from these cells. Comparison of the amino acid sequence with those of other glycosyltransferases revealed that this I-branching enzyme and another $\beta-1,6-N$-acetylglucosaminyltransferase that forms a branch in $O$-glycans are strongly homologous in the center of their putative catalytic domains. Moreover, the genes encoding these two $\beta-1,6-N$-acetylglucosaminyltransferases were found to be located at the same locus on chromosome 9, band q21. These results indicate that the I-branching enzyme represents a member of a $\beta-1,6-N$-acetylglucosaminyltransferase gene family of which expression is controlled by developmental programs.
\end{abstract}

[Key Words: Developmental I antigen; fetal/adult erythrocytes; $\beta-1,6-N$-acetylglucosaminyltransferase; oligosaccharide branching; poly- $N$-acetyllactosamines; expression cloning]

Received November 23, 1992; revised version accepted January 11, 1993.

Glycoconjugates are major components of the outer surface of mammalian cells and their carbohydrate structures change dramatically during the mammalian developmental process. Specific sets of carbohydrates are characteristic for different stages of differentiation, and very often these carbohydrates are recognized by specific antibodies, thus providing differentiation antigens (Feizi 1985; Fukuda 1985). In the mature organism, expression of distinct carbohydrates is eventually restricted to specific cell types, and aberrations in these cell-surface carbohydrates are very often associated with malignant transformation (Hakomori 1984). The functional significance of the alterations in cell-surface carbohydrates during cell differentiation and in malignancy is not completely understood at present, although several reports suggest that these molecules are involved in the modulation of adhesive processes.

${ }^{3}$ Corresponding author.
It has been generally accepted that each glycosyltransferase catalyzes only one enzymatic reaction to form a specific linkage, with one notable exception for the Lewis fucosyltransferase, which can synthesize both $\alpha 1,3$ and $\alpha 1,4$ linkages (Prieels et al. 1981; KukowskaLatallo et al. 1990). Such formation of a specific linkage is usually associated with the formation of specific oligosaccharides in conjunction with other glycosyltransferases. Therefore, it can be anticipated that the presence of specific oligosaccharides on the cell-surface is a result of the coordinate expression of the glycosyltransferase genes responsible for their synthesis. Although in recent years cDNAs have been obtained for approximately a dozen different glycosyltransferases (Paulson and Colley 1989; Schachter 1991; Joziasse 1992), little is known about their regulation during development and in malignancy.

The blood group i/I antigens were the first alloantigens identified that display a dramatic change during human development (Wiener et al. 1956). The $\mathrm{i}$ antigen is 


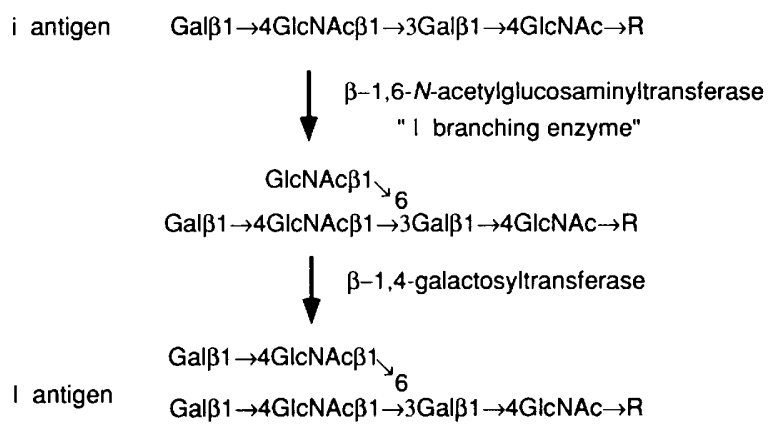

Figure 1. Structure and biosynthesis of $i$ and I antigens. The $i$ antigen is expressed by linear poly- $N$-acetyllactosaminoglycans and is converted into the $I$ antigen by the stepwise addition of a GlcNAc $\beta 1 \rightarrow 6$ and a Gal $\beta 1 \rightarrow 4$ residue. Adapted from Fukuda et al. (1979) and Piller et al. (1984).

expressed on erythrocytes of the fetus and neonate, whereas it is replaced by the I antigen on erythrocytes in the majority of adults (Marsh 1961). During mouse embryogenesis, it was shown that the I antigen is expressed throughout the preimplantation period, whereas the $\mathrm{i}$ antigen is first detected in the 5-day embryo. This expression of the $\mathrm{i}$ antigen is more pronounced in the primary endoderm, and the increase in the $i$ antigen is associated with a decrease in the I antigen (Kapadia et al. 1981; Knowles et al. 1982). The determinants that define the $\mathrm{i} / \mathrm{I}$ antigens have been characterized, and it has been shown that they are carried by linear and branched polylactosaminoglycans, respectively (Feizi et al. 1979; Watanabe et al. 1979). Polylactosaminoglycans are composed of repeats of $\mathrm{N}$-acetyllactosamine $[$ Gal $\beta 1 \rightarrow 4$ GlcNAc $\beta 1 \rightarrow 3$ (Fukuda 1985)], and the conversion of the $i$ into the $I$ antigen is the result of the expression of a $\beta-1,6-N$-acetylglucosaminyltransferase, the I-branching enzyme [IGnT (Fukuda et al. 1979; Piller et al. 1984); (Fig. 1)]. These polylactosaminoglycans are very often modified to provide cell type-specific oligosaccharide structures. One of these structures, sialyl $\mathrm{Le}^{\mathrm{x}}$ or NeuNAc $\alpha 2 \rightarrow 3 \mathrm{Gal} \beta 1 \rightarrow 4$ (Fuc $\alpha 1 \rightarrow 3$ )GlcNAc $\rightarrow$ R (Fukuda et al. 1984), serves as a ligand for the E- and P-selectins, thus playing a critical role in the adhesion of leukocytes to endothelial cells and platelets (Lowe et al. 1990; Phillips et al. 1990; Walz et al. 1990). Another example is the stage-specific embryonic antigen SSEA-1 (Solter and Knowles 1978). This antigen is expressed at the eight-cell stage of mouse embryonic development and then restricted to specific cell types during later stages of murine development. The SSEA-1 molecule was found to be a fucosylated oligosaccharide in which fucose is attached through $\alpha$-1,3-linkage to $\mathrm{N}$-acetyllactosamine, forming Gal $\beta 1 \rightarrow 4$ (Fuc $\alpha 1 \rightarrow 3$ )GlcNAc $\rightarrow$ R (Gooi et al. 1981). By using anti-SSEA-1 antibody or oligosaccharides containing a Gal $\beta 1 \rightarrow 4$ (Fuc $\alpha 1 \rightarrow 3$ )GlcNAc terminus as inhibitors, it was demonstrated that the SSEA-1 molecule might participate in adhesive events that are involved in compaction in early embryogenesis (Bird and Kimber 1984; Fenderson et al. 1984).
In addition to the expression of IGnT, the levels of polylactosaminoglycan synthesis are controlled by the expression of two other $\beta-1,6-N$-acetylglucosaminyltransferases, $N$-acetylglucosaminyltransferase $\mathrm{V}$ for $N$-glycans (Van den Eijnden et al. 1988) and core $2 \beta$-1,6$\mathrm{N}$-acetylglucosaminyltransferase [C2GnT (Fukuda et al. 1986; Yousefi et al. 1991)] for O-glycans. The expression of the latter two enzymes appears to be differentially regulated during differentiation (Piller et al. 1988) and in malignancy (Yamashita et al. 1984; Pierce and Arango 1986; Brockhausen et al. 1991; Saitoh et al. 1991; Yousefi et al. 1991). Because these $\beta-1,6-N$-acetylglucosaminyltransferases are likely to regulate carbohydrate-protein interactions during development and in malignancy by regulating the amount of poly- $\mathrm{N}$-acetyllactosamine and their terminal structures, it will be essential to determine their gene structures and to define the mechanisms for the regulation of their expression.

In this report we describe the transient expression cloning of cDNA encoding the I-branching enzyme using Chinese hamster ovary $(\mathrm{CHO})$ cells that stably express the polyoma virus large $T$ antigen (Heffernan and Dennis 1991). Expression of the polyoma virus large $T$ antigen allows the replication of a plasmid vector harboring the polyoma virus origin of replication in these $\mathrm{CHO}$ cells. Recently, this approach led us to obtain cDNA encoding $\mathrm{C} 2 \mathrm{GnT}$, the enzyme responsible for the formation of the core 2 branch [Gal $\beta 1 \rightarrow 3$ (GlcNAc $\beta 1 \rightarrow 6$ )GalNAc] in $O$-glycans (Bierhuizen and Fukuda 1992). The nucleotide and deduced amino acid sequences of the newly isolated IGnT were found to have limited but clear homology with the corresponding sequence of $\mathrm{C} 2 \mathrm{GnT}$. In addition, we found that the two genes encoding these two different $\beta-1,6-N$-acetylglucosaminyltransferases are located at the same locus on chromosome 9, demonstrating a direct relationship between the two genes.

\section{Results}

\section{Expression cloning and sequence of $c D N A$}

It has been shown that $\mathrm{CHO}$ cells express the linear $\mathrm{i}$ antigen (Sasaki et al. 1987; Smith et al. 1990). Recently, we have established a $\mathrm{CHO}$ cell line (CHO-Py $\cdot$ leu) that stably expresses the polyoma virus large $\mathrm{T}$-antigen, enabling transient expression cloning by using vectors that have the polyoma virus replication origin (Bierhuizen and Fukuda 1992). This CHO cell line neither reacted with anti-I antibodies (Step, Ma) in a panning assay nor stained with anti-I antibodies using immunofluorescence techniques. Because PA-1 human teratocarcinoma cells express a large amount of I-branched structures in their polylactosaminoglycans (Fukuda et al. 1985), a cDNA expression library from poly $\mid \mathrm{A})^{+}$RNA of PA-1 cells was prepared in the mammalian expression vector pcDNAI and screened for cDNA that directed the expression of the I antigen. After transfection, cells expressing the I antigen were enriched by panning using anti-I antibodies, and plasmid DNA was recovered from adherent cells by the Hirt procedure (Hirt 1967). After DpnI treatment to remove plasmids that were not replicated in 
Figure 2. DNA and translated amino acid sequences of IGn'T. The full-length nucleotide and amino acid sequences of IGnT are shown. The signal/membrane-anchoring domain is doubly underlined. Potential $\mathrm{N}$-glycosylation sites are marked by asterisks $\left({ }^{*}\right)$. The sequences are numbered relative to the translation initiation site.

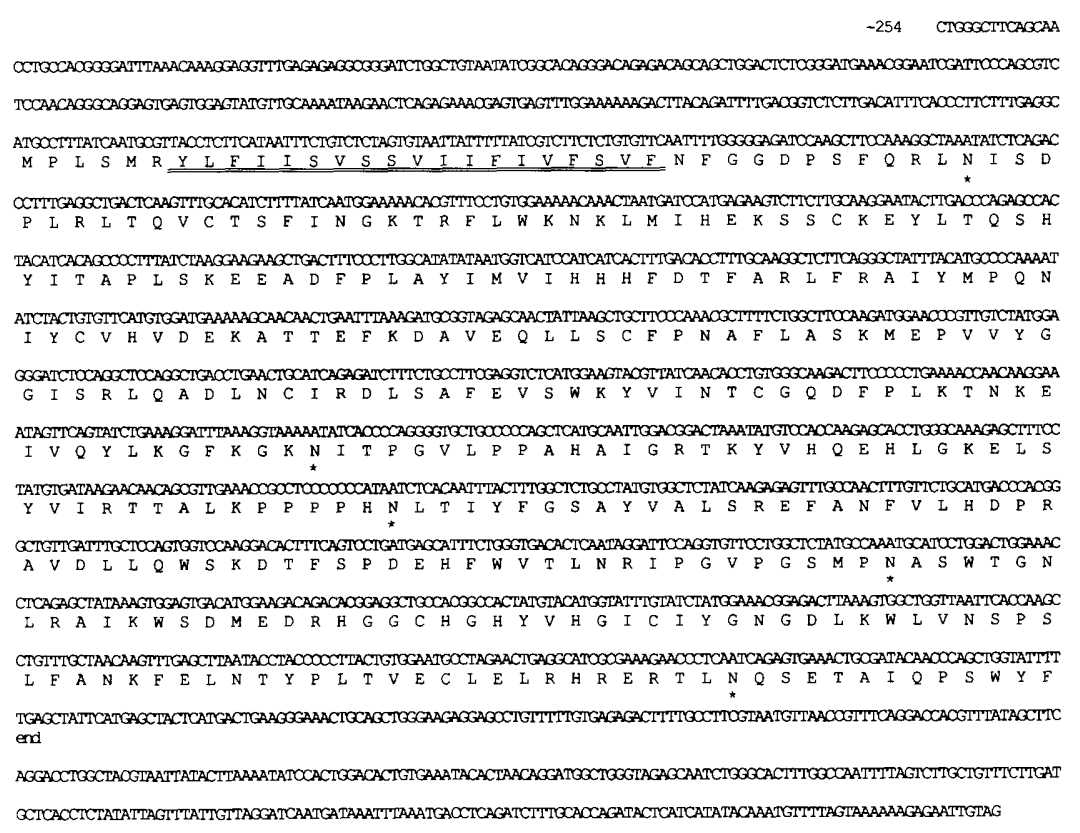

$-241$ transfected cells, plasmid DNA was amplified in the host bacteria and used for a second round of screening by the same procedure. After the second enrichment, the transformants prepared by the Hirt procedure were divided into small pools, and plasmid DNA was prepared again from each plate. Plasmid DNA was then transfected separately into the CHO-Py - leu cells, and the transfectants were screened by immunofluorescence using anti-I antibodies. One of the plasmid pools was selected, and subsequent rounds of sibling selection with sequentially smaller, active pools identified a single plasmid (pcDNAI-IGnT) that directed the expression of the $I$ antigen at the cell-surface.

The cDNA insert of $1807 \mathrm{bp}$ in size contains a single open reading frame in the sense orientation with respect to the pcDNAI promoter (Fig. 2). This reading frame predicts a protein of 400 amino acids in length, with a molecular mass of 45,860 . Hydropathy analysis predicts that this protein has a type II transmembrane topology as has been shown for all mammalian glycosyltransferases cloned to date (Paulson and Colley 1989; Schachter 1991; Joziasse 1992). In this topology a very short cytoplasmic amino-terminal segment of 6 amino-acid residues is followed by a 19-amino-acid transmembrane domain that is flanked by basic amino acid residues. The carboxy-terminal sequence presumably consisting of stem and catalytic domains is large and most likely resides in the lumen of the Golgi complex. Because a consensus sequence for polyadenylation could not be found in the $3^{\prime}$-flanking sequence, it is likely that during construction of the library cDNA synthesis started at an A-rich sequence (nucleotides 1537-1547; see Fig. 2), rather than at the poly(A) tail.

This cloned cDNA hybridized to a single prominent 4.4-kb transcript in poly $(\mathrm{A})^{+}$RNA from PA-1 cells (Fig. $3 \mathrm{~A}$, lane $3 \mid$, whereas it was not detected in poly $(\mathrm{A})^{+}$
A

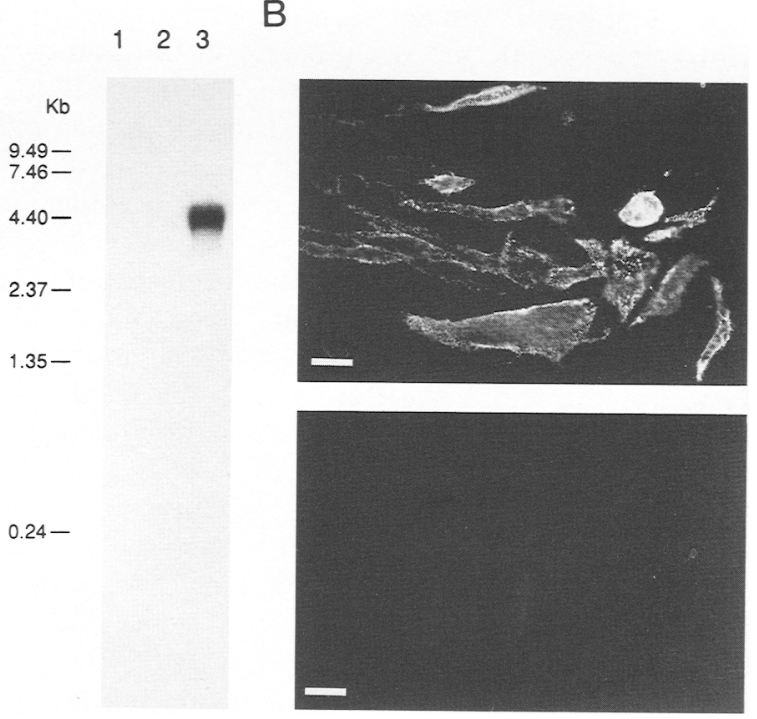

Figure 3. Northern blot analysis of IGnT mRNA $(A)$ and expression of the I antigen by pcDNAI-IGnT $(B) .(A)$ Each lane contained $12 \mu \mathrm{g}$ of poly $(\mathrm{A})^{+}$RNA from CHO-Py leu (lane 1), HL-60 promyelocytic (lane 2), or PA-1 teratocarcinoma (lane 3) cells. A ${ }^{32}$ P-labeled IGnT cDNA fragment representing the complete, putative lumenal part of IGnT was used as a probe for Northern analysis. Only PA-1 cells express the IGnT mRNA. The migration positions of the RNA size markers are indicated at left. $(B)$ Cells transfected with pcDNAI-IGnT (top) and pcDNAI itself (bottom) were examined by immunofluorescence staining with anti-I serum (Ma). Sixty-four hours after transfection the cells were fixed and examined by incubation with human anti-I serum $(\mathrm{Ma})$ in $1: 100$ dilution followed by fluorescein isothiocyanate-conjugated goat anti-human IgM. While mock-transfected cells did not express the I antigen (bottom), the cells transfected with pcDNAI-IGnT expressed significant amounts of the I antigen (top). Bar, $20 \mu \mathrm{m}$. 
RNA isolated from CHO-Py $\cdot$ leu or HL-60 cells under the high stringent conditions for washings (Fig. 3A, lanes $1,2)$. This result is consistent with the reported presence of the I antigen in PA-1 cells (Fukuda et al. 1985) and its absence in CHO (Sasaki et al. 1987; Smith et al. 1990) and HL-60 cells (Mizoguchi et al. 1984; Lee et al. 1990).

\section{Expression of the I antigen directed by the cloned cDNA}

As shown in Figure 3B, CHO-Py $\cdot$ leu cells, transfected with pcDNAI-IGnT, express the I antigen recognized by human anti-I antibody (Ma). The cells transfected with pcDNAI itself showed no staining at all. To confirm that the isolated cDNA encodes for IGnT, CHO cells were stably transfected with both pcDNAI-IGnT and pSV2neo and, as a control, with pSV2neo alone. After selection with G418, clonal cell lines were isolated by limiting dilution. The cells obtained will be referred to as $\mathrm{CHO}-$ neo - IGnT and CHO-neo, respectively. CHOneo - IGnT cells, as well as the control CHO-neo cells, were metabolically labeled with $\left[{ }^{3} \mathrm{H}\right]$ galactose, and glycopeptides were prepared from the labeled cells by pronase digestion and analyzed by G-50 gel filtration.

Figure 4A demonstrates that $\mathrm{CHO}-\mathrm{neo} \cdot \mathrm{IGnT}$ cells produced more glycopeptides with larger molecular mass than CHO-neo cells. When these glycopeptides were digested with endo- $\beta$-galactosidase (Fukuda and Mat- sumura 1976), the glycopeptides from CHO-neo $\cdot$ IGnT cells were more resistant to the enzyme treatment and yielded much less disaccharide, GlcNAc $\beta 1 \rightarrow 3 \mathrm{Gal}$ (Fig. 4A). This disaccharide can be produced only from a linear poly- $\mathrm{N}$-acetyllactosamine chain that contains at least three $\mathrm{N}$-acetyllactosamine repeats (Fukuda et al. 1978,1979 ). On the other hand, the branched galactose present in the I antigen is resistant to endo- $\beta$-galactosidase treatment (Fukuda et al. 1978). These results are therefore in good agreement with the presence of the I antigenic structure in CHO-neo - IGnT cells. Finally, methylation analysis of the $\left[{ }^{3} \mathrm{H}\right]$-galactose-labeled glycopeptides demonstrated the presence of galactose substituted at positions 3 and 6 (2,4-di-O-methylgalactose) in CHO-neo - IGnT cells, which was absent in the control CHO-neo cells (peak in Fig. 4B). Taken together, these results clearly demonstrate that the $\mathrm{CHO}-$ neo - IGnT cells acquired the GlcNAc $\beta 1 \rightarrow 6$ linkage as a result of the expression of IGnT.

\section{IGnT and C2GnT are homologous to each other}

When this newly isolated sequence was tested for homology, no significant similarity was found with any other sequences in our protein data base. In addition, sequence comparison with glycosyltransferases cloned by others, including $\beta-1,2-N$-acetylglucosaminyltransferase I (Kumar et al. 1990; Sarkar et al. 1991) and $\beta-1,4-$
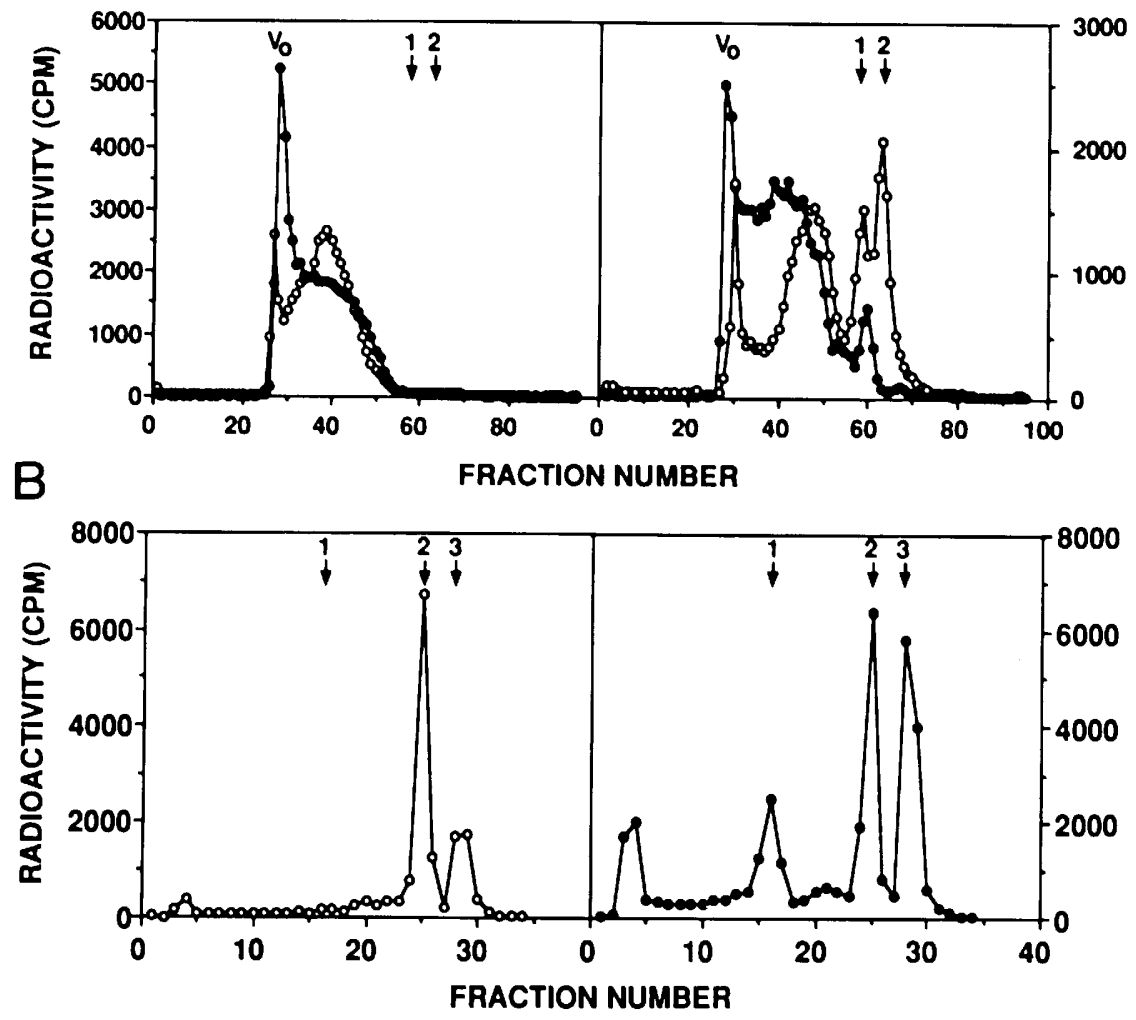

Figure 4. Analysis of polylactosaminoglycans from $\mathrm{CHO}-$ neo and $\mathrm{CHO}-$ neo $\cdot$ IGnT cells. (A) Sephadex G-50 gel filtration of $\left[{ }^{3} \mathrm{H}\right]$ galactose-labeled glycopeptides from CHO-neo (O) and CHO-neo.IGnT (O) cells. High-molecular-weight glycopeptides were prepared by pronase digestion of $\left[{ }^{3} \mathrm{H}\right]$ galactose-labeled cells and applied to a column of Sephadex G-50 before (left) or after (right) endo- $\beta$-galactosidase treatment. The elution positions of standard structures are (1) NeuNAc $\alpha 2 \rightarrow 3 \mathrm{Gal} \beta 1 \rightarrow 4 \mathrm{GlcNAc} \beta 1 \rightarrow$ 3Gal; (2) GlcNAc $\beta 1 \rightarrow 3 \mathrm{Gal}$. (B) Methylation analysis of $\left[{ }^{3} \mathrm{H}\right]$ galactose-labeled glycopeptides. The glycopeptides as shown in $A$ (left were subjected to methylation analysis. The partially $O$-methylated galactose residues were separated by thin layer chromatography. The elution positions of standard methylated galactose residues are indicated: (1) 2,4-di-O-methylgalactose; (2) 2,4,6-tri-O-methylgalactose; (3) 2,3,4,6tetra- $O$-methylgalactose. The occurrence of 2,4-di-O-methylgalactose residues in CHO-neo - IGnT cells (peak 1, right), as opposed to $\mathrm{CHO}-$ neo cells (left), clearly indicates the presence of galactose substituted at both the 3-and 6-positions in $\mathrm{CHO}$-neo - IGnT cells. 


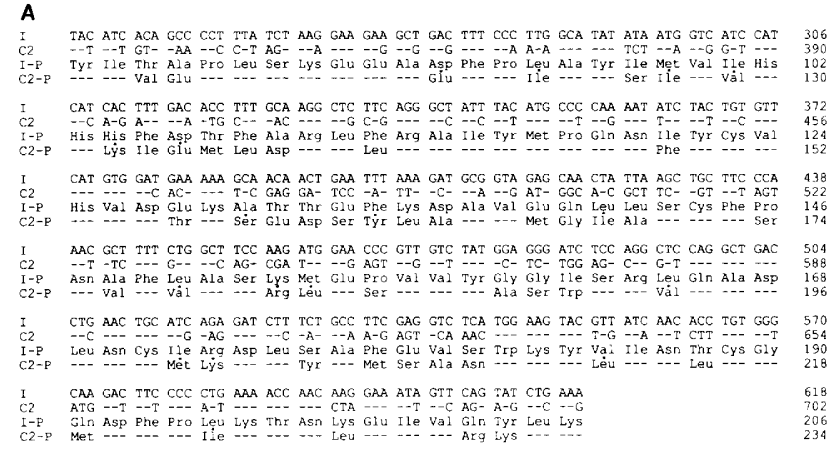

B

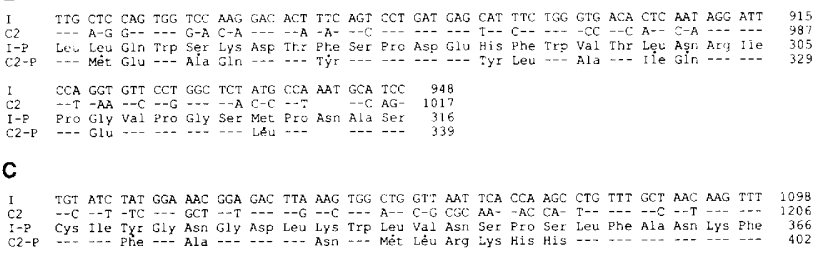

Figure 5. Homology between IGnT and C2GnT. I, C2, I-P, and $\mathrm{C} 2-\mathrm{P}$ designate nucleotide and amino acid sequences of IGnT and $\mathrm{C} 2 \mathrm{GnT}$, respectively. The residues are numbered with respect to the translation initiation site. Identical residues are indicated by dashes; nonidentical but similar amino acids are denoted by dots. $(A)$ The region with long homology; $(B, C)$ regions with modest homology.

$\mathrm{N}$-acetylglucosaminyltransferase III (Nishikawa et al. 1992), did not reveal any similarity.

We have recently cloned a cDNA encoding C2GnT (Bierhuizen and Fukuda 1992). This enzyme adds a GlcNAc $\beta 1 \rightarrow 6$ residue to Gal $\beta 1 \rightarrow 3$ GalNAc but not to Gal $\beta 1 \rightarrow 4$ GlcNAc. When the sequence of IGnT was compared with $\mathrm{C} 2 \mathrm{GnT}$, limited but distinct homology was found in both cDNA and deduced amino acid sequences. The amino acid sequences of the two enzymes are significantly homologous in the presumed catalytic domain (Fig. 5A). Comparison of the cDNA sequence of the two enzymes demonstrated homology in the carboxy-terminal half of the catalytic domain as well (Fig.

IGnT

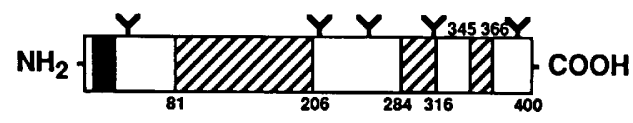

C2GnT

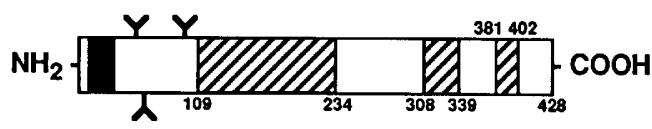

Figure 6. Comparison of the domain structures and homologous regions of two $\beta-1,6-N$-acetylglucosaminyltransferases, IGnT and C2GnT. Alignment of the two $\beta-1,6-N$-acetylglucosaminyltransferases cloned to date revealed a homologous region of 126 amino acid residues with $60 \%$ sequence identity, 33 (or 32) amino acid residues with $61 \%$ identity, and 22 amino acid residues with $59 \%$ identity (hatched boxes). Solid boxes denote signal anchor domain; $\mathbf{Y}$ denotes potential $\mathrm{N}$-glycosylation sites.

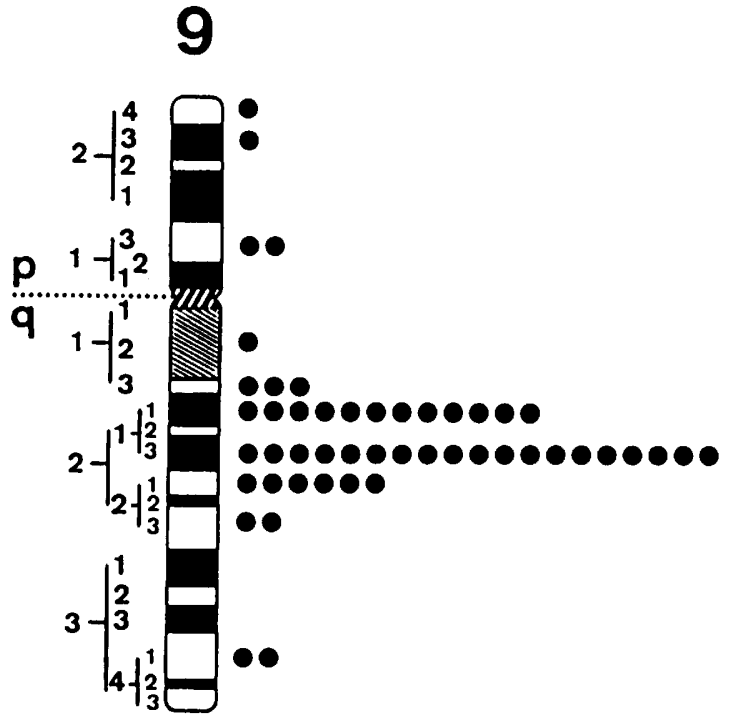

Figure 7. Distribution of labeled sites on chromosome 9 for C2GnT. Of 100 metaphase cells examined for hybridization, 241 silver grains were associated with chromosomes and 49 $(20.3 \%)$ were located on chromosome 9 . Seventy-six percent of them were mapped to the q21.1-q22.1 region of the chromosome 9 long arm, with a maximum at the q21 band. Almost identical results were obtained for IGnT, except for an additional minor peak at p23 of chromosome 6 .

$5 \mathrm{~B}, \mathrm{C})$. However, the homology in the amino acid sequences of this portion is not as long as the aforementioned. The location of the homologous region with respect to the protein sequence is schematically represented in Figure 6. Taken together, these results suggest that the two $\beta-1,6-N$-acetylglucosaminyltransferases are related to each other.

The genes encoding the two $\beta$-1,6-N-acetylglucosaminyltransferases are related to each other

To further understand how these two proteins are related, chromosomal localization of these genes was determined by in situ chromosome hybridization. As shown in Figure 7, the gene encoding $\mathrm{C} 2 \mathrm{GnT}$ was found to be localized at the chromosome 9, q21 band. Surprisingly, the gene encoding IGnT was found to be localized at the same locus (results not shown).

To further understand the relationship between IGnT and $\mathrm{C} 2 \mathrm{GnT}$, the genomic structures coding for the two enzymes were examined. First, the genomic sequences of the two enzymes were amplified by polymerase chain reaction (PCR) using genomic DNA as template. The 5' and $3^{\prime}$ primers were synthesized according to the $5^{\prime}$ - and $3^{\prime}$ - flanking sequences of the cDNAs. The results showed that the products amplified from the genomic DNA are the same size as that expected from the amplification of the cDNA sequences $(1589 \mathrm{bp}$ for IGnT and 
A

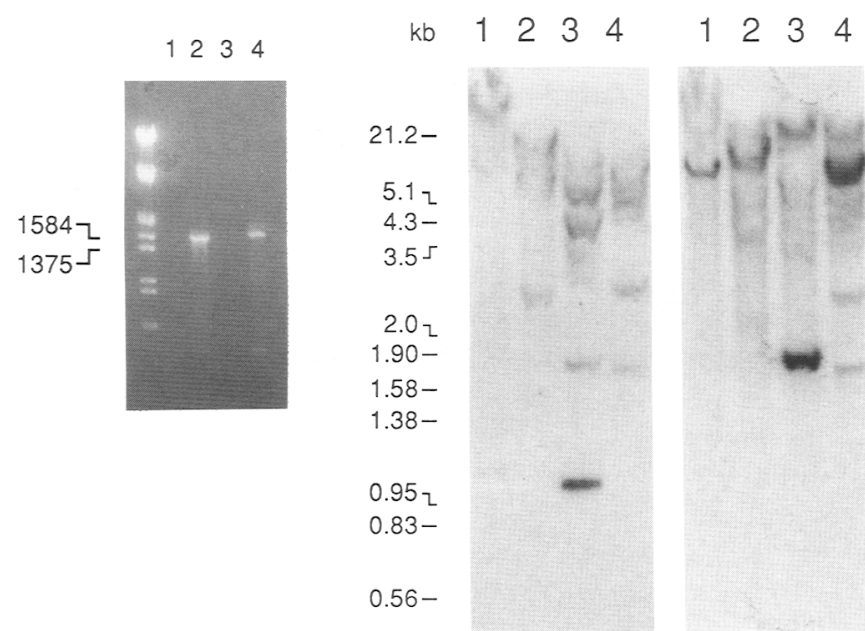

Figure 8. Separation of genomic sequences obtained by PCR $(A)$ and Southern blot analysis of human genomic DNA using IGnT- and C2GnT-specific sequences as probes $(B) .(A)$ The nucleotide sequences of IGnT and C2GnT were amplified by PCR, as described in Materials and methods, and separated by agarose-gel electrophoresis. The $5^{\prime}$ and $3^{\prime}$ primers for PCR were synthesized according to the 5'- and 3'-flanking sequences of cDNA encoding IGnT or C2GnT. The numbers at left denote the size of two molecular mass markers (in bp), which are similar in size to the PCR products. (Lanes 1,2) C2GnT; (lanes 3,4) IGnT. Lanes 1 and 3 were control experiments without template genomic DNA. (B) Genomic DNA prepared from HL-60 cells was digested separately with BamHI, EcoRI, HindIII, and $X b a I$ (lanes 1-4, respectively), and aliquots of the digestions were separated in duplicate by agarose-gel electrophoresis. The blots were probed with the cDNA insert of IGnT or C2GnT that encompasses only their putative intralumenal domain. Relative mobility of molecular mass markers is indicated at left (in kb). Among the restriction enzymes employed, there is no restriction site in the coding sequence for BamHI, EcoRI, and XbaI.

1553 bp for C2GnT) (Fig. 8A). The results strongly suggest that the complete coding sequences for both IGnT and $\mathrm{C} 2 \mathrm{GnT}$ are located in one exon.

We then examined the genomic DNA by Southern blot hybridization using IGnT- and C2GnT-specific sequences as probes under the low stringent conditions. In these experiments, we tried to detect as many genomic sequences related to IGnT or C2GnT as possible. First, some of the revealed bands could be ascribed to the coding sequences; for example, the 1.1- and 1.6-kb HindIII fragments represent the coding sequence for $\mathrm{C} 2 \mathrm{GnT}$ and IGnT, respectively (Fig. 8B). The results also reveal that the two sequences cross-hybridized with the two cDNA probes. Second, there are several genomic fragments that hybridized with one cDNA probe but not with the other cDNA probe. In particular, a HindIII fragment of $\sim 16 \mathrm{~kb}$ in size and a $X b a \mathrm{I}$ fragment of $\sim 12 \mathrm{~kb}$ in size were detected by the IGnT probe but not by the C2GnT probe. In addition, $\mathrm{XbaI}$ digestion yielded at least four fragments that were detected by both probes despite the fact that there is no $\mathrm{XbaI}$ restriction site in either of the cDNAs. Considering that there is no intron in these sequences, these results strongly suggest that there is at least one more gene that is related to IGnT and/or C2GnT.

The results obtained suggest that IGnT and $\mathrm{C} 2 \mathrm{GnT}$ belong to a family of $\beta-1,6-N$-acetylglucosaminyltransferases, which probably arose by gene duplication and subsequent divergence.

\section{Discussion}

The present study describes the isolation of a cDNA clone encoding IGnT, the enzyme responsible for the formation of the GlcNAc $\beta 1 \rightarrow 3($ GlcNAc $\beta 1 \rightarrow 6)$ Gal structure. The formation of this structure results in the I antigen, $\mathrm{Gal} \beta 1 \rightarrow 4 \mathrm{GlcNAc} \beta 1 \rightarrow 3 \mid \mathrm{Gal} \beta 1 \rightarrow$ 4GlcNAc $\beta 1 \rightarrow 6$ ) Gal (Fig. 1), because $\beta 1$,4-galactosyltransferase is expressed almost ubiquitously in mammalian cells. For this cloning, a CHO cell line that stably expresses the polyoma large $\mathrm{T}$ antigen was used (Heffernan and Dennis 1991; Bierhuizen and Fukuda 1992), allowing the replication of a plasmid vector harboring a polyoma replication origin such as pcDNAI.

There are four different $\beta 1 \rightarrow 6-N$-acetylglucosaminyl linkages: GlcNAc $\beta 1 \rightarrow 3($ GlcNAc $\beta 1 \rightarrow 6)$ Gal, the IGnT product (Piller et al. 1984); Gal $\beta 1 \rightarrow 3($ GlcNAc $\beta 1 \rightarrow$ 6)GalNAc, the core 2 structure (Piller et al. 1988); GlcNAc $\beta 1 \rightarrow 3$ (GlcNAc $\beta 1 \rightarrow 6$ )GalNAc, the core 4 structure (Brockhausen et al. 1985); and GlcNAc $\beta 1 \rightarrow$ 2 (GlcNAc $\beta 1 \rightarrow 6$ ) Man, the $N$-acetylglucosaminyltransferase V product (Cummings et al. 1982). The enzymes responsible for all of these linkages share the same unique property that $\mathrm{Mn}^{2+}$ is not required for their activity. Only the cDNAs encoding IGnT and C2GnT have been cloned so far. As described recently (Bierhuizen and Fukuda 1992), C2GnT acts exclusively on Gal $\beta 1 \rightarrow 3$ GalNAc and not on other substrates. Because another study suggests that there is a $\beta-1,6-N$-acetylglucosaminyltransferase in tracheal epithelium that can form core 2, core 4, and I structures (Ropp et al. 1991), there must be at least one other glycosyltranferase related to IGnT and C2GnT. Southern blot hybridization of human genomic DNA with IGnT- and C2GnT-specific probes indicates that there is at least one additional sequence related to $\mathrm{C} 2 \mathrm{GnT}$ and IGnT.

The present study demonstrates that the genes for IGnT and $\mathrm{C} 2 \mathrm{GnT}$ are located at the same locus on chromosome 9 . The present study also showed that the entire coding sequence for both enzymes is located in a single exon. In combination with the observed structural homology, these results point toward the possibility that the different $\beta-1,6-N$-acetylglucosaminyltransferases belong to a gene family and that they probably evolved by gene duplication and subsequent divergence. There are precedents for the presence of gene families concerning glycosyltransferases. For $\alpha$-1,3-galactosyltransferase, for example, it has been demonstrated that both the blood group A and B transferases (Yamamoto et al. 1990) and a human pseudogene related to bovine and murine 
Gal $\beta 1 \rightarrow 4$ GlcNAc $\alpha$-1,3-galactosyltransferase (Shaper et al. 1992) are located on human chromosome 9q33-34. Similarly, it has been shown that at least two $\alpha 1,3$ fucosyltransferases (FucTIII and FucTV) are related to each other, and the genes encoding these two enzymes were found to reside on chromosome 19 (Weston et al. 1992). The coding sequences of these two fucosyltransferases are also located in one exon. If these genes are localized at the same locus on chromosome 19, it is likely that these two fucosyltransferases also evolved from a common precursor gene.

All of the glycosyltransferases cloned so far share a common type II transmembrane topology, consisting of a short amino-terminal cytoplasmic sequence, a signalanchor sequence followed by a short stem region, and a large carboxy-terminal catalytic domain. Apart from this common topology, IGnT and C2GnT have no apparent homology with other glycosyltransferases, including two other $N$-acetylglucosaminyltransferases. When the amino acid sequences of $\mathrm{IGnT}$ and $\mathrm{C} 2 \mathrm{GnT}$ are compared, a limited but distinct homology can be noticed. As shown in Figure 6, the region of the extensive homology is located around the center of the presumed catalytic domain. In addition, the sequence close to the carboxyterminal region also has some homology in the two enzymes. As shown previously, this intralumenal portion contains the catalytic domain /Colley et al. 1989; Kukowska-Latallo et al. 1990; Bierhuizen and Fukuda 1992).

More recently, it has been demonstrated (Wen et al. 1992) that there is a homology in part of the amino acid sequences among three different sialyltransferases: Gal $\beta 1 \rightarrow 3(4)$ GlcNAc $\alpha-2,3$, Gal $\beta 1 \rightarrow 3$ GalNAc $\alpha-2,3$, and $\mathrm{Gal} \beta 1 \rightarrow 4 \mathrm{GlcNAc} \alpha-2,6$ sialyltransferases. The region of this homology lies in the center of the catalytic domains of these enzymes. The region of homology between the two $\beta-1,6-N$-acetylglucosaminyltransferases (IGnT and $\mathrm{C} 2 \mathrm{GnT}$ ) lies in a similar place with respect to the domain structures of the glycosyltransferases (Fig. 6). However, the extent of the homology is much more significant between IGnT and C2GnT than between the three sialyltransferases. Because this homology is not observed with other $N$-acetylglucosaminyltransferases, it is unlikely that this homologous region represents the binding site for UDP-GlcNAc. In the $\beta-1,6-N$-acetylglucosaminyltransferase gene family there are additional regions close to the carboxyl terminus where distinct homology exist (Fig. 6). It is thus possible that these three homologous sequences are close to each other once the polypeptides are folded to form the three-dimensional structures. If this is the case, the conserved sequences are essential to form the correct framework, allowing specific amino acids to bind to the acceptor.

In relation to this, it is worthy to mention the structure formed by the carbohydrate recognition domain of $\mathrm{C}$-type lectins. The three-dimensional structure of one of these proteins was elucidated recently (Weis et al. 1992), and the results strongly suggest that such conserved amino acid residues in the carbohydrate recognition domain are involved in generating the folding patterns that should be shared by different C-type lectins. Moreover, some of those residues are also involved in calcium or carbohydrate binding.

The availability of a cDNA clone encoding the I-branching enzyme now enables us to regulate the amount of the I branchings by regulating the transcription level of the I-branching enzyme. For example, it will be possible to express the I branchings in sialyl $\mathrm{Le}^{\mathbf{x}}$-expressing cells and then test whether such branches increase the binding to E-selectin. It will also be possible to reduce or abolish the expression of the I-branching enzyme by anti-sense technology or gene knockout in transgenic mice. Such experiments will be important in future studies to determine whether I branching plays a critical role during embryonic development and differentiation.

It is noteworthy that the expression of all of the $\beta-1,6-$ $\mathrm{N}$-acetylglucosaminyltransferases changes dramatically during development and oncogenesis. The occurrence of the I antigen is closely associated with development and maturation of erythroid cells (Marsh 1961; Fukuda et al. 1979), whereas the formation of the core 2 structure in $\mathrm{O}$-glycans has been observed in a variety of biological processes such as T-cell activation (Piller et al. 1988) and immunodeficiency due to the Wiskott-Aldrich syndrome (Piller et al. 1991) and AIDS (Saitoh et al. 1991). On the other hand, an increase in the activities of $\mathrm{N}$-acetylglucosaminyltransferase $\mathrm{V}$ and $\mathrm{C} 2 \mathrm{GnT}$ has been associated with malignant transformation (Yamashita et al. 1984; Pierce and Arango 1986; Yousefi et al. 1991). The present study suggests that these enzymes, which change dramatically during development and oncogenesis, might have evolved from a common precursor gene. It is possible, therefore, that their expression is regulated by common regulatory genomic elements as well as intrinsic genomic elements. Thus, the genomic relationship of the different $\beta 1,6-N$-acetylglucosaminyltransferases and their regulation in expression during development and oncogenesis will be of paramount interest in understanding the roles of carbohydrates in development and oncogenesis.

\section{Materials and methods \\ Construction of stably transfected CHO cells expressing the polyoma virus large $T$ antigen}

The plasmid vectors pPSVEI-PyE, harboring the polyoma virus early genes (Muller et al. 1984), and pZIPneo-leu, harboring leukosialin (CD43) and neomycin cDNA, were constructed as described (Bierhuizen and Fukuda 1992). Polyoma large $T$ antigen and human leukosialin-expressing cell lines were established by cotransfecting CHODG44 cells with pPSVEI-PyE and pZIPneo-leu and by subsequent selection for G418 resistance. Polyoma virus large $\mathrm{T}$ antigen-mediated replication of plasmids in these cell lines was assessed by measurement of the methylation status of the recombinant DNA (Heffernan and Dennis 1991) using pcDNAI harboring cDNA-encoding galactosyltransferase (Aoki et al. 1992). One particular cloned CHO cell line, designated $\mathrm{CHO}-\mathrm{Py} \cdot \mathrm{leu}$, was used for transient expression cloning (Seed and Aruffo 1987). 


\section{Isolation of a human IGnT cDNA clone}

A cDNA library, pcDNAI-PA-1, was constructed from poly $|\mathrm{A}|^{+}$ RNA isolated from human PA-1 teratorcarcinoma cells and the mammalian expression vector pcDNAI (Invitrogen, San Diego, CA). This cDNA library was screened similarly as described (Bierhuizen and Fukuda 1992). Briefly, plasmid DNA was transfected into $\mathrm{CHO}-\mathrm{Py} \cdot$ leu cells using lipofectin, and the transfected cells were detached at $37^{\circ} \mathrm{C}$ in PBS/ 5 mM EDTA (pH 7.4) after a $64-\mathrm{hr}$ expression period. The detached cells were pooled, centrifuged, and resuspended in cold PBS, containing $10 \mathrm{~mm}$ EDTA, $10 \%$ fetal calf serum ( $\mathrm{pH} 7.4)$, and human anti-I antibodies (Step) as serum in $1: 100$ dilution. After a 1-hr incubation on ice, the cells were washed and panned on dishes coated with goat anti-human IgM (Sigma, St. Louis, MO), prepared as described (Wysocki and Sato 1978). Anti-I antibodies from two patients (Step and Ma) were kindly donated by Dr. Eloise Giblett (Blood Bank Center, Seattle, WA). Plasmid DNA was rescued (Hirt 1967) from transfected CHO-Py - leu cells adherent to the panning dishes, digested with DpnI to remove plasmids that were not replicated in transfected cells, and transformed into the host Escherichia coli MC1061/P3 (Seed and Aruffo 1987). Plasmid DNA was prepared again and used for an additional round of screening by the same procedure. E. coli transformants thus prepared from this second enrichment were plated to yield four pools of $\sim 2000$ colonies each. Plasmid DNA prepared from each plate was transfected separately into CHO-Py - leu cells, and the transfected cells were screened by panning as described above. One of the plasmid pools yielded relatively more attached and partially agglutinated cells. Transformants corresponding to this group were plated again to yield eight pools of $\sim 500$ colonies each, and replica plates were made. Plasmid DNA was prepared from the replica plates and transfected separately into $\mathrm{CHO}-\mathrm{Py} \cdot \mathrm{leu}$ cells; transfectants were then screened for the expression of the I antigen by immunofluorescence, as described below. One of the plasmid pools was selected, and three subsequent rounds of sibling selection with sequentially smaller active pools identified a single plasmid, pcDNAI-IGnT, that determined the expression of the I antigen at the cell-surface.

\section{Immunofluorescence microscopy}

Sixty-four hours after transfection, transfected cells were fixed with $0.05 \% p$-formaldehyde in PBS and stained with human anti-I antibody (Ma or Step) as serum in $1: 100$ dilution, followed by fluorescein-conjugated goat anti-human IgM (Sigma, St. Louis, MO). The cells were then examined under a Zeiss Axioplan microscope as described previously /Williams and Fukuda 1990).

\section{Sequencing}

The cDNA insert of pcDNAI-IGnT was sequenced by the chain-termination method (Sanger et al. 1977) using oligonucleotide primers synthesized according to the flanking sequences in the plasmid. The sequence was then extended by using oligonucleotide primers synthesized according to the sequences obtained within the cDNA insert.

\section{Northern blot analysis}

Poly $(\mathrm{A})^{+}$RNA prepared using a commercial kit (Stratagene, La Jolla, CA) was resolved by electrophoresis in a $1.2 \%$ agarose- 2.2 $M$ formaldehyde gel and then blotted onto a nylon membrane (Micro Separations, Inc., MA) (Sambrook et al. 1989). The puta- tive catalytic domain of IGnT was amplified by PCR /Saiki et al 1988 ), labeled with $\left.{ }^{32} \mathrm{P}\right] \mathrm{dCTP}$ by a random priming method (Feinberg and Vogelstein 1983), and used as a probe. Hybridizations were performed at $42^{\circ} \mathrm{C}$ in buffers containing $50 \%$ formamide for $24 \mathrm{hr}$, and blots were then washed several times in $0.1 \times$ SSPE $/ 0.1 \%$ SDS at $42^{\circ} \mathrm{C}$ for several hours (Sambrook et al. 1989 ) before exposure to Kodak XAR film at $-70^{\circ} \mathrm{C}$.

\section{Southern blot analysis}

Genomic DNA was prepared from HL-60 cells as described (Sambrook et al. 1989) and subjected to Southern blotting and hybridization as described previously (Siebert and Fukuda 1986). Briefly, the blots were hybridized with cDNA probes in $6 \times$ SSPE, $0.5 \%$ SDS, $50 \mu \mathrm{g} / \mathrm{ml}$ of denatured, sheared salmon sperm DNA containing $50 \%$ formamide at $42^{\circ} \mathrm{C}$ for $16 \mathrm{hr}$, and then washed in $2 \times \mathrm{SSPE} / 0.5 \% \mathrm{SDS}$ at room temperature for several hours. The probe used was identical to the one used for Northern blot analysis. Similarly, the putative catalytic domain of $\mathrm{C} 2 \mathrm{GnT}$ was amplified by PCR as described previously (Bierhuizen and Fukuda 1992) and used as a probe after labeling by a random priming method.

\section{Amplification of genomic DNA sequences by $P C R$}

The genomic sequences encoding IGnT and $\mathrm{C} 2 \mathrm{GnT}$ were amplified by PCR using HL-60 genomic DNA as a template. The $5^{\prime}$ and $3^{\prime}$ primers for amplification of the IGnT gene start at the sequence 154 nucleotides upstream from the initiation codon and 232 nucleotides after the stop codon, respectively. The 5' and $3^{\prime}$ primers for amplification of the $\mathrm{C} 2 \mathrm{GnT}$ gene start at the sequence 125 nucleotides upstream from the initiation codon and 141 nucleotides after the stop codon, respectively. Amplification of genomic DNA was repeated 35 times under the following conditions: denaturation for $1 \mathrm{~min}$ at $94^{\circ} \mathrm{C}$, annealing for $2 \mathrm{~min}$ at $55^{\circ} \mathrm{C}$, and polymerization for $5 \mathrm{~min}$ at $68^{\circ} \mathrm{C}$. After amplification, the PCR products were subjected to $1.0 \%$ agarose gel electrophoresis.

\section{Establishment of CHO cells stably expressing the I-branching enzyme}

CHODG44 cells were transfected either alone with pSV2neo or with pSV2neo and pcDNAI-IGnT using a calcium phosphate technique (Graham and Van der Eb 1973) and subsequently selected for G418 resistance. Clonal cell lines were obtained by limiting dilution, and two cell lines, designated $\mathrm{CHO}-$ neo and CHO-neo $\cdot$ IGnT, respectively, were selected.

\section{Analysis of glycopeptides from $\mathrm{CHO}-n e o$ and CHO-neo $\cdot$ IGnT cells}

The CHO cells were metabolically labeled with $\left[{ }^{3} \mathrm{H}\right]$ galactose $(10 \mu \mathrm{Ci} / \mathrm{ml})$ in $\alpha$-MEM supplemented with $10 \%$ fetal calf serum for $24 \mathrm{hr}$. The labeled cells were harvested with a rubber policeman, washed with PBS, and collected by centrifugation. The cell pellets were then extracted with 10 volumes of chloroformmethanol $[2: 1,(\mathrm{vol} / \mathrm{vol})]$ as described (Fukuda et al. 1985). The cell residues were digested with pronase for $24 \mathrm{hr}$ at $60^{\circ} \mathrm{C}$ in a toluene atmosphere. The digest was then boiled for $10 \mathrm{~min}$ to denature the remaining enzyme. After centrifugation, the supernatants were applied to a column $(1.0 \times 110 \mathrm{~cm})$ of Sephadex G-50 (Superfine) equilibrated with $0.1 \mathrm{M} \mathrm{NH}_{4} \mathrm{HCO}_{3}$. High-molecular-weight glycopeptides were pooled and desalted, and a portion of them was subjected to endo- $\beta$-galactosidase treatment (Fukuda and Matsumura 1976). The digested glycopep- 
tides and control glycopeptides were subjected to the same Sephadex G-50 gel filtration. Endo- $\beta$-galactosidase from Escherichia freundii was kindly provided by Dr. Michiko Fukuda of this institute.

\section{Methylation analysis}

The glycopeptides obtained from the $\left[{ }^{3} \mathrm{H}\right]$ galactose-labeled $\mathrm{CHO}-$ neo and $\mathrm{CHO}-$ neo $\cdot$ IGnT cells were purified as described above and were then methylated as described (Ciucanus and Kerek 1984|. Nonradioactive glycopeptides prepared from fetuin (Sigma, St. Louis, MO) were added as carrier before methylation. The methylated glycopeptides were dissolved in chloroform, washed five times with water, and dried under a nitrogen stream. The methylated glycopeptides were then hydrolyzed in $3 \mathrm{~N} \mathrm{HCl}$ for $3 \mathrm{hr}$ at $80^{\circ} \mathrm{C}$. After drying the hydrolysates under a nitrogen stream, the partially methylated galactose residues were dissolved in a small volume of chloroform-methanol [1:1, (vol/vol)], applied to a silica gel G plate, and subjected to thin layer chromatography in acetone/water/ammonium hydroxide $[250: 3: 1.5(\mathrm{vol} / \mathrm{vol} / \mathrm{vol})]$ as described (Lee et al. 1990). After chromatography, the sample lanes were separated into $0.5-\mathrm{cm}$ sections, and the radioactivity was determined by liquid scintillation counting.

\section{In situ chromosome hybridization}

In situ hybridization was carried out on chromosome preparations obtained from phytohemagglutinin-stimulated human lymphocytes cultured for $72 \mathrm{hr}$. The conditions for labeling probes, hybridization, and washing were as described previously (Nguyen et al. 1986). After coating with nuclear truck emulsion (Kodak $\mathrm{NTB}_{2}$ ), the slides were exposed for 19 days at $4^{\circ} \mathrm{C}$ and developed. To avoid any slipping of silver grains during the banding procedure, chromosome spreads were first stained with a buffered Giemsa solution and metaphases were photographed. R-banding was then performed by the fluorescence-photolysisGiemsa method, and the metaphases were photographed before analysis. In general, 100-200 metaphase cells were examined for minimizing the statistical error caused by background staining.

\section{Acknowledgments}

We thank Dr. Michiko Fukuda for useful discussions, Dr. Eloise Giblett for the kind gift of anti-I antisera, Ms. Michelle Ansari for technical assistance, and Ms. Melissa Moore for secretarial assistance. This work was supported by grants CA33895 and CA33000 awarded by the National Cancer Institute (to M.F.) and grants awarded by the Association Pour La Recherche Contre Le Cancer (to M.-G.M.).

The publication costs of this article were defrayed in part by payment of page charges. This article must therefore be hereby marked "advertisement" in accordance with 18 USC section 1734 solely to indicate this fact.

\section{Note}

The sequence data described in this paper have been submitted to the EMBL/GenBank data libraries under accession number Z19550.

\section{References}

Aoki, D., N. Lee, N. Yamaguchi, C. Dubois, and M.N. Fukuda. 1992. Golgi retention of a trans-Golgi membrane protein, galactosyltransferase, requires cysteine and histidine residues within the membrane-anchoring domain. Proc. Natl. Acad. Sci. 89: 4319-4323.

Bierhuizen M.F.A. and M. Fukuda. 1992. Expression cloning of cDNA encoding UDP-GlcNAc : Gal $1 \rightarrow 3$ GalNAc $\rightarrow$ R (GlcNAc to GalNAc) $\beta-1,6-N$-acetylglucosaminyltransferase by gene transfer into $\mathrm{CHO}$ cells expressing polyoma large $\mathrm{T}$ antigen. Proc. Natl. Acad. Sci. 89: 9326-9330.

Bird, J.M. and S.J. Kimber. 1984. Oligosaccharides containing fucose linked $\alpha(1-3)$ and $\alpha(1-4)$ to $N$-acetylglucosamine cause decompaction of mouse morulae. Dev. Biol. 104: 449-460.

Brockhausen, I., K.L. Matta, J. Orr, and H. Schachter. 1985. Mucin synthesis. UDP-GlcNAc: GalNAc-R $\beta 3-N$-acetylglucosaminyltransferase and UDP-GlcNAc: GlcNAc $\beta 1 \rightarrow$ 3GalNAc-R (GlcNAc to GalNAc) $\beta 6-N$-acetylglucosaminyltransferase from pig and rat colon mucosa. Biochemistry 24: 1866-1874.

Brockhausen, I., W. Kuhns, H. Schachter, K.L. Matta, D.R. Sutherland, and M.A. Baker. 1991. Biosynthesis of O-glycans in leukocytes from normal donors and from patients with leukemia: Increase in O-glycan core 2 UDPGlcNAc: Gal $\beta 3$ GalNAc $\alpha-R / G l c N A c$ to GalNAc) $\beta(1-6)-N$ acetylglucosaminyltransferase in leukemic cells. Cancer Res. 51: 1257-1263.

Ciucanus, I. and F. Kerek. 1984. A simple and rapid method for the permethylation of carbohydrates. Carbohydr. Res. 131: 209-217.

Colley, K.J., E.U. Lee, B. Adler, J.K. Browne, and J.C. Paulson. 1989. Conversion of a Golgi apparatus sialyltransferase to a secretory protein by replacement of the $\mathrm{NH}_{2}$-terminal signal anchor with a signal peptide. I. Biol. Chem. 264: 1761917622.

Cummings, R.D., I.S. Trowbridge, and S. Kornfeld. 1982. A mouse lymphoma cell line resistant to the leucoagglutinating lectin from Phaseolus vulgaris is deficient in UDPGlcNAc : $\alpha$-D-mannoside $\quad \beta 1 \rightarrow 6 N$-acetylglucosaminyltransferase. J. Biol. Chem. 257: 13421-13427.

Feinberg, A.P. and B. Vogelstein. 1983. A technique for radiolabeling DNA restriction endonuclease fragments to high specific activity. Anal. Biochem. 132: 6-13.

Feizi, T. 1985. Demonstration by monoclonal antibodies that carbohydrate structures of glycoproteins and glycolipids are onco-developmental antigens. Nature 314: 53-57.

Feizi, T., R.A. Childs, K. Watanabe, and S. Hakomori. 1979. Three types of blood group I specificity among monoclonal anti-I autoantibodies revealed by analogues of a branched erythrocyte glycolipid. I. Exp. Med. 149: 975-980.

Fenderson, B.A., U. Zehavi, and S. Hakomori. 1984. A mulivalent lacto- $N$-fucopentaose III-lysyllysine conjugate decompacts preimplantation mouse embryo, while the free oligosaccharide is ineffective. J. Exp. Med. 160: 1591-1596.

Fukuda, M. 1985. Cell-surface glycoconjugates as onco-differentiation markers in hematopoietic cells. Biochim. Biophys. Acta 780: 119-150.

Fukuda, M.N. and G. Matsumura. 1976. Endo- $\beta$-galactosidase of Escherichia freundii. Purification and endoglycosidic action on keratan sulfates, oligosaccharides, and blood group active glycoprotein. J. Biol. Chem. 251: 6218-6225.

Fukuda, M.N., K. Watanabe, and S. Hakomori. 1978. Release of oligosaccharides from various glycosphingolipids by endo- $\beta$ galactosidase. J. Biol. Chem. 253: 6814-6819.

Fukuda, M., M.N. Fukuda, and S. Hakomori. 1979. The devel- 
opmental change and genetic defect in carbohydrate structure of band 3 glycoprotein of human erythrocyte membranes. J. Biol. Chem. 254: 3700-3703.

Fukuda M., E. Spooncer, J.E. Oates, A. Dell, J.C. Klock. 1984. Structure of sialylated fucosyl lactosaminoglycan isolated from human granulocytes. J. Biol. Chem. 259: 10925-10935.

Fukuda M.N., A. Dell, J.E. Oates, and M. Fukuda. 1985. Embryonal lactosaminoglycan: The structure of branched lactosaminoglycans with novel disialosyl (sialyl $\alpha 2 \rightarrow 9$ sialyl) terminals isolated from PAl human embryonal carcinoma cells. J. Biol. Chem. 260: 6623-6631.

Fukuda, M., S.R. Carlsson, J.C. Klock, and A. Dell. 1986. Structures of O-linked oligosaccharides isolated from normal granulocytes, chronic myelogenous leukemia cells, and acute myelogenous leukemia cells. J. Biol. Chem. 261: 12796-12806.

Gooi, H.C., T. Feizi, A. Kapadia, B.B. Knowles, D. Solter, and M.J. Evans. 1981. Stage-specific embryonic antigen involves $\alpha 1 \rightarrow 3$ fucosylated type 2 blood group chains. Nature 292: $156-158$.

Graham, F.L. and A.J. Van der Eb. 1973. A new technique for the assay of infectivity of human adenovirus 5 DNA. Virology 52: $456-467$.

Hakomori, S. 1984. Tumor-associated carbohydrate antigens. Annu. Rev. Immunol. 2: 103-126.

Heffernan, M. and J.W. Dennis. 1991. Polyoma and hamster papovavirus large $\mathrm{T}$ antigen-mediated replication of expression shuttle vectors in Chinese Hamster Ovary cells. Nucleic Acids Res. 19: 85-92.

Hirt, B. 1967. Selective extraction of polyoma DNA from infected mouse cell cultures. J. Mol. Biol. 26: 365-369.

Joziasse, D.H. 1992. Mammalian glycosyltransferases: Genomic organization and protein structure. Glycobiology 2: 271277.

Kapadia, A., T. Feizi, and M.J. Evans. 1981. Changes in the expression and polarization of blood group $i$ and I antigens in postimplantation embryos and teratocarcinomas of mouse associated with cell differentiation. Exp. Cell Res. 131: 185195.

Knowles, B.B., J. Rappaport, and D. Solter. 1982. Murine embryonic antigen (SSEA-1) is expressed on human cells and structurally related human blood group antigen $I$ is expressed on mouse embryos. Dev. Biol. 93: 54-58.

Kukowska-Latallo, J.F., R.D. Larsen, R.P. Nair, and J.B. Lowe. 1990. A cloned human cDNA determines expression of a mouse stage-specific embryonic antigen and the Lewis blood group $\alpha(1,3 / 1,4)$ fucosyltransferase. Genes \& Dev. 4: 12881303.

Kumar, R., J. Yang, R.D. Larsen, P. Stanley. 1990. Cloning and expression of $\mathrm{N}$-acetylglucosaminyltransferase I, the medial Golgi transferase that initiates complex $N$-linked carbohydrate formation. Proc. Natl. Acad. Sci. 87: 9948-9952.

Lee, N., W.-C. Wang, and M. Fukuda. 1990. Granulocytic differentiation of HL-60 cells is associated with increase of poly- $N$-acetyllactosamine in Asn-linked oligosaccharides attached to human lysosomal membrane glycoproteins. I. Biol. Chem. 265: 20476-20487.

Lowe, J.B., L.M. Stoolman, R.P. Nair, R.D. Larsen, T.L. Berhend, and R.M. Marks. 1990. ELAM-1-dependent cell adhesion to vascular endothelium determined by a transfected human fucosyltransferase cDNA. Cell 63: 475-484.

Marsh, W.L. 1961. Anti-i: Cold antibody defining the li relationship in human red cells. Br. J. Haematol. 7: 200-209.

Mizoguchi, A., S. Takasaki, S. Maeda, and A. Kobata. 1984. Changes in asparagine-linked sugar chains of human promyelocytic leukemic cells (HL-60) during monocytoid differen- tiation and myeloid differentiation. Decrease of high-molecular-weight oligosaccharides in acidic fraction. $J$. Biol. Chem. 259: 11949-11957.

Muller, W. J., M.A. Naujokas, and J.A. Hassell. 1984. Isolation of large $\mathrm{T}$ antigen-producing mouse cell lines capable of supporting replication of polyomavirus-plasmid recombinants. Mol. Cell. Biol. 4: 2406-2412.

Nguyen, C., M.-G. Mattei, J.-F. Mattei, M.-J. Santoni, C. Goridis, and B.R. Jordan. 1986. Localization of the human NCAM gene to band q23 of chromosome 11: The third gene coding for a cell interaction molecule mapped to the distal portion of the long arm of chromosome 11. J. Cell Biol. 102: 711715.

Nishikawa, A., Y. Ihara, M. Hatakeyama, K. Kangawa, and N. Taniguchi. 1992. Purification, cDNA cloning and expression of UDP- $N$-acetylglucosamine : $\beta$-D-mannoside $\beta-1,4-N$ acetylglucosaminyltransferase III from rat kidney. I. Biol. Chem. 267: 18199-18204.

Paulson, J.C. and K.J. Colley. 1989. Glycosyltransferases. Structure, localization, and control of cell type-specific glycosylation. J. Biol. Chem. 264: 17615-17618.

Phillips, M.L., E. Nudelman, F.C.A. Gaeta, M. Perez, A.K. Singhal, S. Hakomori, and J.C. Paulson. 1990. ELAM-1 mediates cell adhesion by recognition of a carbohydrate ligand, sialyl$\mathrm{Le}^{\mathrm{x}}$. Science 250: 1130-1132.

Pierce, M., and J. Arango. 1986. Rous sarcoma virus-tranformed baby hamster kidney cells express higher levels of asparagine-linked tri- and tetraantennary glycopeptides containing [GlcNAc- $\beta(1,6) \mathrm{Man}-\alpha(1,6) \mathrm{Man}]$ and poly- $N$-acetyllactosamine sequences than baby hamster kidney cells. J. Biol. Chem. 261: 10772-10777.

Piller, F., J.-P. Cartron, A. Maranduba, A. Veyrieres, Y. Leroy, and B. Fournet. 1984. Biosynthesis of blood group I antigens. Identification of a UDP-GlcNAc: GlcNAc $\beta 1 \rightarrow 3 \mathrm{Gal}(-$ R) $\beta 1 \rightarrow 6$ (GlcNAc to Gal) $N$-acetylglucosaminyltransferase in hog gastric mucosa. J. Biol. Chem. 259: 13385-13390.

Piller, F., V. Piller, R.I. Fox, and M. Fukuda. 1988. Human T-lymphocyte activation is associated with changes in O-glycan biosynthesis. I. Biol. Chem. 263: 15146-15150.

Piller, F., F. Le Deist, K.I. Weinberg, R. Parkman, and M. Fukuda. 1991. Altered O-glycan synthesis in lymphocytes from patients with Wiskott-Aldrich Syndrome. J. Exp. Med. 173: $1501-1510$.

Prieels, J.-P., D. Monnom, M. Dolmans, T.A. Beyer, and R.L. Hill. 1981. Co-purification of the Lewis blood group $N$-acetylglucosaminide $\alpha 1 \rightarrow 4$ fucosyltransferase and an $N$-acetylglucosaminide $\alpha 1 \rightarrow 3$ fucosyltransferase from human milk. J. Biol. Chem. 256: 10456-10463.

Ropp, P. A., M.R. Little, and P.-W. Cheng. 1991. Mucin biosynthesis: Purification and characterization of a mucin $\beta 6 \mathrm{~N}$ acetylglucosaminyltransferase. J. Biol. Chem. 266: 2386323871.

Saiki, R.K, D.H. Gelfand, S. Stoffel, S.J. Scharf, R. Higuchi, G.T. Horn, K.B. Mullis, and H.A. Erlich. 1988. Primer-directed enzymatic amplification of DNA with a thermostabile DNA polymerase. Science 239: 487-491.

Saitoh, O., F. Piller, R.I. Fox, and M. Fukuda. 1991. T-lymphocytic leukemia expresses complex, branched $O$-linked oligosaccharides on a major sialoglycoprotein, leukosialin. Blood 77: 1491-1499.

Sambrook, J., E.F. Fritsch, and T. Maniatis. 1989. Molecular cloning: A laboratory manual, 2nd ed. Cold Spring Harbor Laboratory Press, Cold Spring Harbor, New York.

Sanger, F., S. Nicklen, and A.R. Coulson. 1977. DNA sequencing with chain-terminating inhibitors. Proc. Natl. Acad. Sci. 74: 5463-5467. 
Sarkar, M., E. Hull, Y. Nishikawa, R.J. Simpson, R.L. Moritz, R. Dunn, and H. Schachter. 1991. Molecular cloning and expression of cDNA encoding the enzyme that controls conversion of high-mannose to hybrid and complex $N$-glycans: UDP- $N$-acetylglucosamine $\alpha$-3-D-mannoside $\beta-1,2-N$ acetylglucosaminyltransferase I. Proc. Natl. Acad. Sci. 88: 234-238.

Sasaki, H., B. Bothner, A. Dell, and M. Fukuda. 1987. Carbohydrate structure of erythropoietin expressed in Chinese hamster ovary cells by a human erythropoietin cDNA. $J$. Biol. Chem. 262: 12059-12076.

Schachter, H. 1991. Enzymes associated with glycosylation. Curr. Opin. Struct. Biol. 1: 755-765.

Seed, B. and A. Aruffo. 1987. Molecular cloning of the CD2 antigen, the T-cell erythrocyte receptor, by a rapid immunoselection procedure. Proc. Natl. Acad. Sci. 84: 3365-3369.

Shaper, N.L., S. Lin, D.H. Joziasse, Y.K. Do, and T.L. Yangfeng. 1992. Assignment of two human $\alpha 1$,3-galactosyltransferase gene sequences (GGTAl and GGTAIP) to chromosome 9q33-q43 and chromosome 12q14-q15. Genomics 12: 613615.

Siebert, P.D. and M. Fukuda. 1986. Human glycophorin A and B are encoded by separate, single copy genes coordinately regulated by a tumor-promoting phorbol ester. $/$. Biol. Chem. 261: 12433-12436.

Smith, D.F., R.D. Larsen, S. Mattox, J.B. Lowe, and R.D. Cummings. 1990. Transfer and expression of a murine UDPGal : $\beta$-D-Gal- $\alpha 1$,3-galactosyltransferase in Chinese hamster ovary cells. J. Biol. Chem. 265: 6225-6234.

Solter, D. and B.B. Knowles. 1978. Monoclonal antibody defining a stage-specific mouse embryonic antigen (SSEA-1). Proc. Natl. Acad. Sci. 75: 5565-5569.

Van den Eijnden, D.H., A.H.L. Koenderman, and W.E.C.M. Schiphorst. 1988. Biosynthesis of blood group i-active polylactosaminoglycans. Partial purification and properties of an UDP-GlcNAc : $N$-acetyllactosaminide $\beta 1 \rightarrow 3-N$-acetylglucosaminyltransferase from Novikoff tumor cell ascites fluid. I. Biol. Chem. 263: 12461-12471.

Walz, G., A. Aruffo, W. Kolanus, M. Bevilacqua, and B. Seed. 1990. Recognition by ELAM-1 of the sialyl-Le ${ }^{\mathrm{x}}$ determinant on myeloid and tumor cells. Science 250: 1132-1135.

Watanabe, K., S. Hakomori, R.A. Childs, and T. Feizi. 1979. Characterization of a blood group I-active ganglioside. Structural requirements for I and i specificities. J. Biol. Chem. 254: 3221-3228.

Weis, W.I., K. Drickamer, and W.A. Hendrickson. 1992. Stucture of a C-type mannose-binding protein complexed with an oligosaccharide. Nature 360: 127-134.

Wen, D.X., B.D. Livingston, K.F. Medzihradszky, S. Kelm, A.L. Burlingame, and J.C. Paulson. 1992. Primary structure of Gal $\beta 1,3(4)$ GlcNAc $\alpha 2,3$-sialyltransferase determined by mass spectrometry sequence analysis and molecular cloning. Evidence for a protein motif in the sialyltransferase gene family. J. Biol. Chem. 267: 21011-21019.

Weston, B. W., R.P. Nair, R.D. Larsen, and J.B. Lowe. 1992. Isolation of a novel human $\alpha(1,3)$ fucosyltransferase gene and molecular comparison to the human Lewis blood group $\alpha(1,3 / 1,4)$ fucosyltransferase gene. J. Biol. Chem. 267: 41524160.

Wiener, A.S., L.H. Unger, L. Cohen, and J. Feldman. 1956. Typespecific cold autoantibodies as a cause of acquired hemolytic anemia and hemolytic transfusion reactions: Biologic test with bovine red cells. Ann. Intern. Med. 44: 221-240.

Williams, M.A. and M. Fukuda. 1990. Accumulation of membrane glycoproteins in lysosomes requires a tyrosine residue at a particular position in the cytoplasmic tail. J. Cell Biol.
111: 955-966.

Wysocki, L.J. and V.L. Sato. 1978. "Panning" for lymphocytes. A method for cell selection. Proc. Natl. Acad. Sci. 75: 28442848.

Yamamoto, F.-I., H. Clausen, T. White, J. Marken, and S. Hakomori. 1990. Molecular genetic basis of the histo-blood group ABO system. Nature 345: 229-233.

Yamashita, K., T. Ohkura, Y. Tachibana,. S. Takasaki, and A. Kobata. 1984. Comparative study of the oligosaccharides released from baby hamster kidney cells and their polyoma transformant by hydrazinolysis. J. Biol. Chem. 259: 10634 10640 .

Yousefi, S., E. Higgins, Z. Daoling, A. Pollex-Krüger, O. Hindsgaul, and J.W. Dennis. 1991. Increased UDP-GlcNAc : Gal $\beta 1 \rightarrow 3$ GalNAc-R (GlcNAc to GalNAc) $\beta 1 \rightarrow 6-N$ acetylglucosaminyltransferase activity in metastatic murine tumor cell lines. J. Biol. Chem. 266: 1772-1782. 


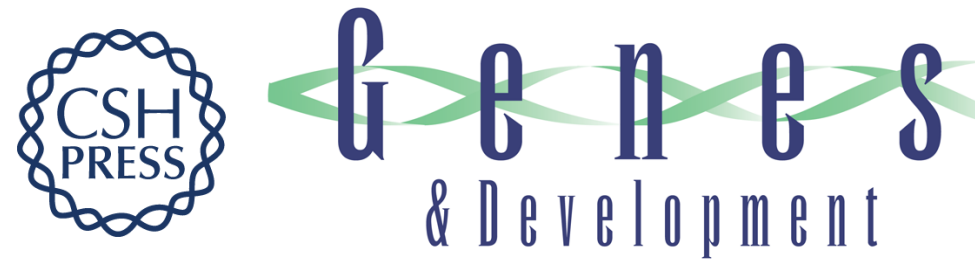

\section{Expression of the developmental I antigen by a cloned human cDNA encoding a member of a beta-1,6- $\mathrm{N}$-acetylglucosaminyltransferase gene family.}

M F Bierhuizen, M G Mattei and M Fukuda

Genes Dev. 1993, 7:

Access the most recent version at doi:10.1101/gad.7.3.468

References This article cites 67 articles, 45 of which can be accessed free at: http://genesdev.cshlp.org/content/7/3/468.full.html\#ref-list-1

License

Email Alerting Service

Receive free email alerts when new articles cite this article - sign up in the box at the top right corner of the article or click here.

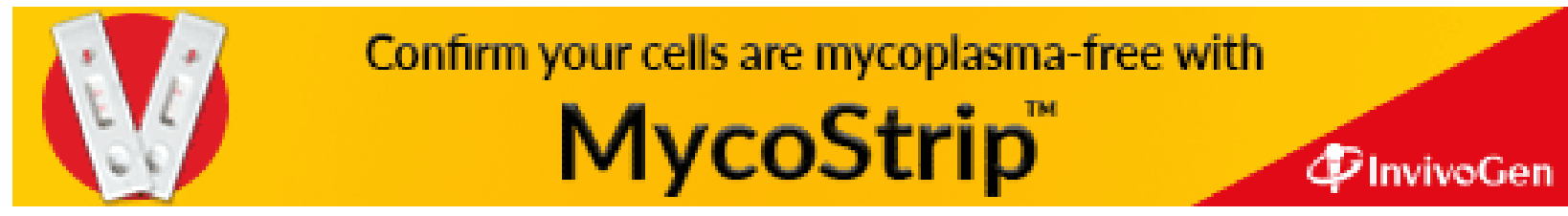

